\title{
Eskalasi Daya Saing Usaha Kelompok Wanita Tani Jawa Timur di Era Revolusi Industri 4.0
}

\author{
${ }^{1}$ Rinurwati ${ }^{*},{ }^{2}$ Muslichah Erma Widiana, ${ }^{3}$ Mahmudah Enny Widyaningrum, \\ ${ }^{4}$ Meidyta Sinantryana Widyaswari \\ Institut Teknologi Sepuluh Nopember (ITS), Surabaya, Indonesia ${ }^{1}$ \\ Universitas Bhayangkara (UBHARA), Surabaya, Indonesia ${ }^{2,3}$ \\ Universitas Nahdlatul Ulama (UNUSA), Surabaya, Indonesia ${ }^{4}$ \\ e-mail: rinur@matematika.its.ac.id ${ }^{1}$,erma@ubhara.ac.id ${ }^{2 *}$,nnymahmudah@yahoo.co.id ${ }^{3}$, \\ Memed85dyta@gmail.com4 \\ *Coresponding Author
}

Submited: July 26, 2021; Revised: August 22, 2021; Accepted: August 22, 2021;

Published: November 12, 2021

\begin{abstract}
ABSTRAK
Produk Kelompok Wanita Tani (KWT) harus memiliki standar mutu yang sesuai dengan keinginan pelanggan. Untuk itu KWT harus memiliki sistem manajemen mutu untuk memastikan kualitas produk yang dihasilkan agar mampu bersaing ditengah era revolusi industry 4.0. Tujuan Pengabdian masyarakat ini adalah KWT dapat bersaing dari pesaingnya dalam merebut perhatian loyalitas konsumen, memperoleh laba yang berkelanjutan dan mempertahankan pasar. Untuk mencapai tujuan tersebut digunakan pendekatan kualitatif dengan melibatkan berbagai disiplin ilmu yaitu statistika dan ekonomi manajemen. Secara makro memberikan manfaat bagi kelompok wanita yang memiliki usaha memanfaatkan potensi daerahnya sehingga produk unggulan daerah semakin tercipta dengan kualitas tinggi. Pengabdian masyarakat dilakukan secara bertahap 1). melakukan pendekatan kualitatif yang difokuskan mengidentifikasi faktor standarisasi produk KWT di Jatim. 2). melakukan pengujian model faktor standarisasi produk. 3). penerapan model pada kelompok usaha wanita lain serta dinas yang terkait. Pada akhir kegiatan didapat bahwa kemasan yang unik dan menarik berperan penting. Kemasan produk IKM Jawa Timur telah mengikuti trend pasar dan sesuai dengan kebutuhan konsumen. Kata kunci: Daya saing, Loyalitas, KWT, Standarisasi
\end{abstract}

\section{ABSTRACT}

In terms of increasing competitiveness, the Women Farmers Group (KWT) products must have quality standards that follow the customer's wishes. For this reason, KWT must have a quality management system to ensure the quality of the product so that they can compete during the era of industrial revolution 4.0. Community service has the goal of KWT's ability to compete with its competitors in capturing the attention of consumer loyalty, obtaining sustainable profits, and maintaining the market. The qualitative approach involves various disciplines, namely statistics and managerial economics. On a macro basis, it provides benefits for groups of women who have businesses to take advantage of the potential of their regions, and superior regional products are increasingly created by high quality. This community service is carried out in stages; 1) carried out a qualitative approach focused on identifying the factors of standardization of KWT products in East Java, 2) testing the KWT product standardization factor model, 3) application of the model to other women's business groups and related agencies. At the end of the activity, unique and attractive packaging was played an important role. East Java IKM product packaging has followed market trends, and it is following consumer needs.

Keywords: Competitiveness, Standardization, Loyalty 


\section{IJECS}

IJECS: Indonesian Journal of Empowerment and Community Services

Vol. 2, No. 2 (2021), pp. 58-69 / p-ISSN: 2745-9438 e-ISSN: 2745-9446

Homepage: http://journal.univetbantara.ac.id/index.php/ijecs

\section{Copyright (C) 2021 The Author(s)}

This is an open-access article under the CC BY-SA license.

\section{PENDAHULUAN}

Perekonomian dan perdagangan merupakan satu kekuatan pada masa globalisasi yang semakin terintegrasi tanpa batasan territorial batas-batas negara-negara di dunia. Di Indonesia Perekonomian dan perdagangan melalui semangat Kartini yang menumbuhkan emansipasi, banyak para wanita yang ikut berperan dalam peningkatan perekonomian tanpa meninggalkan kodrat sebagai seorang ibu. Wanita Indonesia mulai mendapat banyak kesempatan dalam meraih pendidikan bahkan pekerjaan. Pilot project optimasi lahan merupakan domain perempuan sebagai salah satu sektor domestik, kegiatan ini dilaksanakan dengan harapan para perempuan Indonesia memberikan kontribusi yang lebih besar dalam kelangsungan rumah tangga, baik secara fisik, logistik maupun keuangan. Kegiatan optimasi lahan dilaksanakan di 5 propinsi yaitu Jawa Barat, Banten, Jawa Tengah, DIY dan Jawa Timur.

Propinsi Jawa Timur merupakan salah satu propinsi yang terkenal dengan sektor pertaniannya. Dan Sumber Daya Manusia yang memiliki semangat tinggi untuk bertahan dan meningkatkan taraf kehidupannya. Tak terkecuali kelompok-kelompok wanita dengan profesinya sebagai wirausaha. Pada pengabdian masyarakat ini adalah bagaimana hasil-hasil produksi kelompok-kelompok wanita tani yang memiliki potensi sumber daya alam produktif memiliki standart produk sehingga mada masa globalisasi memiliki daya saing.

Jawa Timur mempunyai posisi yang cukup strategis di bidang industri karena diapit oleh dua provinsi besar yaitu Jawa Tengah dan Bali, sehingga menjadi pusat pertumbuhan industri maupun perdagangan. Selain itu Jawa Timur mempunyai potensi di bidang Pertanian, Perkebunan, Niaga, Holtikultura, Perikanan, dan Sumberdaya Energi serta potensi industri yang cukup bagus, hal ini dapat dilihat dari pertumbuhan ekonomi Jawa Timur pada Tahun 2017 sebesar 5,45\% atau 0,38 \% diatas capaian nasional sebesar 5,07\%. Pertumbuhan sektor industri sebesar 5,69 \% atau 1,42\% diatas capaian nasional sebesar 1,42\%. Kontribusi industri terhadap PDRB sebesar 29,03 \%; kontribusi perdagangan terhadap PDRB sebesar 18,18 \%; Kontribusi pertanian terhadap PDRB sebesar 12,08 \%; Kontribusi 14 sektor lainnya terhadap PDRB sebesar $39,98 \%$. Sedangkan sub sektor industri pengolahan tahun 2017 terbesar diperoleh dari industri makanan dan minuman sebesar $31,69 \%$, industri pengolahan tembakau sebesar $26,63 \%$ dan industri kimia dan obat tradisional sebesar 8,03\%.

Melihat kontribusi sub sektor industri pengolahan terbesar terhadap Produk Domestik Regional Bruto (PDRB) Jawa Timur adalah industri makanan minuman, maka perlu dilakukan pembinaan secara berkesinambungan untuk mempertahankan dan meningkatkan daya saing KWT yang mendirikan industri-industri skala RT maupun Usaha Kecil dan Menengah (UKM). Dalam hal peningkatan daya saing, produk KWT harus memiliki standar mutu yang sesuai dengan keinginan pelanggan. Hal ini mau tidak mau KWT harus memiliki sistem manajemen mutu untuk memastikan kualitas produk yang dihasilkan sesuai dengan keinginan pelanggan agar mampu bersaing ditengah era MEA. Oleh sebab itu, penerapan sistem manajemen mutu ISO 9001:2008 dapat menjadi salah satu solusi usaha untuk menjamin mutu.Dalam perkembangan ini, KWT dituntut untuk melakukan pembaharuan-pembaharuan produk atau hasil karya ciptanya baik melalui inovasi, imitasi ataupun yang lainnya. Inovasi ini tercipta karena adanya suatu pesaingan yang menuntut perbaikan kualitas produk, pelayanan ataupun yang lainnya. Memenangkan 
persaingan merupakan hal yang paling krusial bagi pemasar untuk mendapatkan hati para pelanggan. Dengan demikian, pemasar harus mengetahui terlebih dahulu dinamika persaingan atau harus mampu menganalisis pesaing, mencari kelemahannya, serta mencari strategi yang tepat dalam menghadapi pesaingnya.

Daya saing adalah peluang suatu komoditas untuk lebih diterima oleh konsumen atau pasar. Daya saing (competitiveness) suatu produk adalah kemampuan yang berkelanjutan (sustainability) untuk memperoleh keuntungan dan pangsa (share) di pasar dalam negeri dan luar negeri. Faktor memperoleh keuntungan, menembus pasar atau diterima konsumen serta berkelanjutan memerlukan penanganan atau manajemen yang efisien agar tujuan tersebut dapat segera tercapai. Jika menginginkan barang yang akan dijual dapat diterima konsumen tentunya barang tersebut dapat memenuhi kepentingan konsumen. Agar konsumen mau membeli atau menggunakan produk KWT. Produk tersebut harus lebih menarik dan lebih memenuhi kebutuhan dibanding yang lain, selain mempunyai harga lebih murah dan mutunya tetap stabil dari waktu ke waktu. Jika produk tersebut berupa bahan makanan atau yang sejenis seperti kosmetik perlu ada jaminan unsur kesehatan atau kehalalan. Menurut Aris Yaman dan Syahrizal Maulana (2016), daya saing adalah kemampuan perusahaan, industri, daerah, negara, atau antar daerah untuk menghasilkan faktor pendapatan dan faktor pekerjaan yang relatif tinggi dan berkesinambungan untuk menghadapi persaingan internasional. Daya saing perusahaan dicerminkan dari daya saing produk yang dihasilkan. Dapat disimpulkan bahwa daya saing adalah suatu kemampuan perusahaan untuk menciptakan keunggulan pembeda sebuah produk agar dapat tumbuh dan berkembang dengan baik diantara produk-produk sejenis lainnya. Produk Industri Kecil Menengah (IKM) Jawa Timur yang kurang inovatif menyebabkan daya saingnya masih tergolong relatif rendah sehingga diperlukan strategi-strategi peningkatan daya saing di era globalisasi ini melalui perbaikan kualitas secara terus menerus.

Ledy Mardila (2013) mengatakan daya saing adalah kemampuan perusahaan untuk dapat bersaing atau menjadi unggul dari perusahaan pesaingnya dalam merebut perhatian dan loyalitas konsumen, memperoleh laba yang berkelanjutan dan mempertahankan pasar. Sedangkan Sri Irmayanti Tarimana (2017) mendefinisikan daya saing sebagai kemampuan dari suatu industri untuk menunjukkan keunggulan dalam hal tertentu, dengan cara memperlihatkan situasi dan kondisi yang paling menguntungkan, hasil kerja yang lebih baik dibandingkan dengan industri lainnya. Sehingga faktor yang harus diperhatikan dalam persaingan adalah keunggulan.

Hal ini dapat dikatakan bahwa daya saing adalah sebuah kemampuan perusahaan untuk memperlihatkan keunggulan produk yang dihasilkan dibanding pesaingnya sehingga dapat merebut perhatian dan loyalitas konsumen. Keunggulan produk IKM Jawa Timur kurang menonjol dimata konsumen, sehingga hanya sedikit konsumen yang mengonsumsi produkproduk IKM Jawa Timur. Kebanyakan kualitas produk IKM Jawa Timur dianggap remeh oleh konsumen. Konsumen lebih suka mengonsumsi produk-produk impor yang dianggapnya kualitasnya lebih bagus dari produk IKM Jawa Timur dan dengan harga yang relatif lebih murah. Hal ini menyebabkan daya saing produk IKM Jawa Timur relatif lebih rendah dibandingkan produk-produk impor.

Guna menjaga produk KWT mutunya tetap stabil dari waktu ke waktu, maka IKM perlu menerapkan standarisasi secara konsisten. Vincent Gaspersz (2011:359) mengemukakan bahwa ISO 9001 adalah suatu standar internasional untuk sistem manajemen kualitas yang menetapkan 
persyaratan-persyaratan dan rekomendasi dari sistem manajemen kualitas yang bertujuan untuk menjamin bahwa organisasi akan memberikan produk yang sesuai dengan persyaratan yang telah ditetapkan. Saat ini KWT Jawa Timur masih banyak yang belum mamahami pentingnya penerapan ISO 9001 untuk keberlangsungan usahanya, banyak KWT Jawa Timur yang beranggapan bahwa produknya sudah dapat memenuhi kebutuhan konsumen dan memuaskan pelanggan tanpa memikirkan strategi peningkatan kualitas produk.

Tetapi beberapa KWT Jawa Timur belum melakukan pengembangan desain untuk produknya, desain produknya dari tahun ke tahun masih itu-itu saja. Hal ini menyebabkan konsumen merasa jenuh terhadap produk KWT tersebut. Banyak cara yang dapat dilakukan oleh para KWT untuk meningkatkan daya saing. Salah satunya dengan membangun branding. Sayangnya, upaya untuk membangun kekuatan merek masih kurang disadari oleh sebagian besar KWT di Jawa Timur. Saat ini, berbisnis bagi mereka masih dilihat sebagai kegiatan menjual dan mendapatkan keuntungan semata tanpa memikirkan investasi jangka panjang dengan membangun merek. Padahal, seorang yang benar-benar memiliki jiwa entrepreneur, akan secara serius membentuk merek yang kuat melalui berbagai inovasi kreatif. Dengan memiliki merek, produk KWT Jawa Timur akan mudah diingat oleh konsumen. Merek sebagai pembeda dari produk sejenis yang menjadi saingan produk KWT di Jawa Timur bahkan dengan KWT-KWT yang lain di propinsi-propinsi yang ada di Indonesia. Saat ini masih banyak KWT Jawa Timur yang kurang sadar untuk mendaftarkan merek produknya guna mendapatkan perlindungan secara hukum. Saat suatu produk KWT Jawa Timur pemasarannya sudah mulai luas dan tiba-tiba mengetahui bahwa merek yang digunakan adalah milik orang lain, maka dengan terpaksa KWT tersebut harus mengganti merek produknya. Mengingat perlindungan merek pada Kementerian Hukum dan HAM RI memiliki prinsip first to file, sehingga pemerintah, dalam hal ini Dinas Perindustrian dan Perdagangan Provinsi Jawa Timur memberikan pemahaman secara berkesinambungan tentang manfaat perlindungan merek melalui program kegiatan dalam rangka perlindungan maupun pengembangan merek tersebut.

Menurut Sri Irmayanti Tarimana (2017), kemasan adalah aktivitas merancang dan memproduksi wadah atau pembungkus suatu produk. Bungkus atau kemasan yang menarik akan memberikan nilai plus pada konsumen yang sedang membedakan beberapa produk yang bentuk dan mutunya hampir sama. Dapat dikatakan bahwa kemasan adalah kegiatan mendesain pembungkus produk agar dapat melindungi produk yang ada didalamnya dan menjadi daya tarik konsumen untuk membeli produk tersebut. Banyak kemasan produk KWT Jawa Timur yang mirip dengan kemasan lain dengan produk sejenis, sehingga produk tidak menonjol di rak display. Hal ini menyebabkan produk IKM Jawa Timur tidak memiliki ciri khas yang membuat konsumen selalu mengingat produk tersebut. Menurut Aris Yaman dan Syahrizal Maulana (2016) hubungan antara ISO 9001 dengan daya saing produk, terdapat hasil yang menunjukkan peningkatan mutu produk diyakini akan meningkatkan kepuasan pelanggan, dan lebih dari itu, akan meningkatkan daya saing produk tersebut. Suatu perusahaan harus mampu menghasilkan produk yang telah memenuhi persyaratan mutu dan standar-standar tertentu untuk dapat meningkatkan daya saing dalam persaingan global. ISO 9001 merupakan suatu sistem untuk memaksimalkan daya saing sebuah perusahaan melalui perbaikan yang terus-menerus atas pelayanan, proses, output (hasil) dan sumber daya manusia yang memiliki prinsip yakni berfokus pada kepuasan pelanggan, kualitas produk, adanya kerjasama tim serta perbaikan sistem secara berkesinambungan. Produk IKM Jawa Timur belum memiliki jaminan bahwa kualitasnya konsisten sehingga daya saing produknya belum terlihat menonjol. Dengan menerapkan ISO 
9001 maka semua proses dikerjakan sesuai dengan prosedur kerja yang telah ditetapkan serta didukung form-form yang tersedia dengan harapan dapat meningkatkan daya saing produk IKM Jawa Timur.

Christina Ariadne Sekar Sari (2017) mengatakan bahwa merek berpengaruh positif dan signifikan terhadap minat beli konsumen, artinya semakin baik merek dan menguasai pasar, maka dapat meningkatkan minat beli konsumen. Sedangkan Sri Irmayanti Tarimana (2017) berpendapat bahwa secara parsial merek berpengaruh nyata terhadap keputusan pembelian. Dengan meningkatnya keputusan pembelian maka daya saing produk juga akan meningkat. Selain itu sebuah merek juga dapat menjadi sebuah sinyal bagi pelanggan atas sebuah produk, dan melindungi baik pelanggan maupun produsen dari pesaing yang akan berusaha untuk menyediakan produk identik yang akan muncul. Tujuan Pengabdian masyarakat ini adalah KWT dapat bersaing dari pesaingnya dalam merebut perhatian loyalitas konsumen, memperoleh laba yang berkelanjutan dan mempertahankan pasar. Untuk mencapai tujuan tersebut digunakan pendekatan kualitatif dengan melibatkan berbagai disiplin ilmu yaitu statistika dan ekonomi manajemen.

\section{METODE}

\section{Diagram Fishbone}

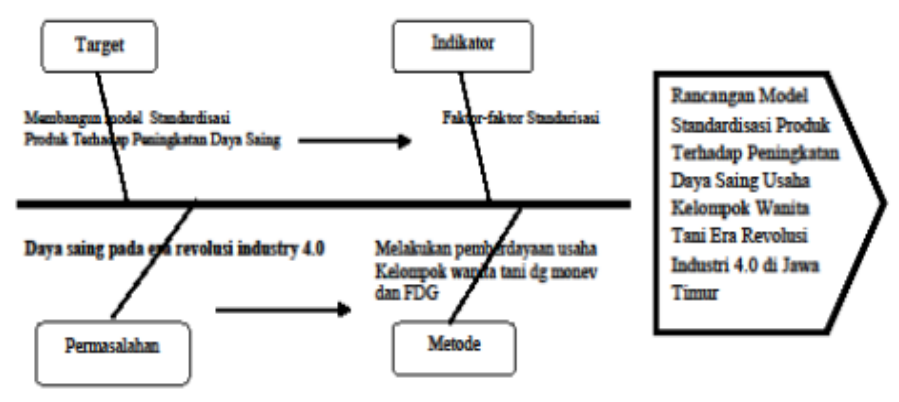

Gambar 1. Diagram Fishbone Pemasalahan Pengabdian masyarakat

\section{Teknik Analisis Pengumpulan data}

a) Usaha kelompok wanita Tani

Identifikasi usaha kelompok wanita tani yang berlangsung di wilayah obyek pengabdian masyarakat Kabupaten Banyuwangi, Bojonegoro. Seberapa kesiapan usaha pada masa era revolusi industry 4.0. Termasuk identifikasi determinan faktor pendukung dan penghambat terlaksananya kegiatan pengelolaan lahan pertanian.

b) Identifikasi Kegiatan Pemasaran

Identifikasi pengembangan model pemasaran relasional berbasis standarisasi yang berlangsung di wilayah obyek pengabdian masyarakat Kabupaten Banyuwangi, Bojonegoro, termasuk identifikasi determinan faktor pendukung dan penghambat terlaksananya pemasaran berbasis standarisasi usaha kelompok wanita tani. Selain kadar keilmiahannya yang tinggi jenis 
pengabdian masyarakat ini dipilih juga sesuai dengan tujuan pengabdian masyarakat yakni menghasilkan model pemasaran standarisasi usaha kelompok wanita tani yang dapat menjadi model yang handal dalam meningkatkan daya saing pemasaran usaha kelompok wanita tani di lingkungan wilayah yang diteliti.

Pada tahap need assessment ini akan digunakan metode focus discussion group. Metode ini sangat baik untuk menggali data dari kalangan aparat dinas perindustrian dan perdagangan, karena dengan metode ini mereka dapat mengekspresikan pendapatnya secara terbuka dan berkelompok. Walaupun demikian dalam pelaksanaan focus discussion group ini, peneliti (pemandu) harus dapat mengajukan problem question dengan cara yang dapat dimengerti dan sesuai dengan responden.

\section{Obyek}

Obyek pengabdian masyarakat ini adalah (1) para wanita tani yang memiliki lahan pertanian (2) para wanita tani yang mengelola produk pertanian lebih lanjut ataukah menjual masih dari hasil pertanian tanpa pengeloaan lebih lanjut. 3) Yang sudah menjual dengan mengolah lebih lanjut dan melakukan kesiapan standarisasinya pada era revolusi industri 4.0. Hasil yang diharapkan pada pengabdian masyarakat tahun pertama; (1) identifikasi usaha wanita tani (2) identifikasi model pengembangan bagi wanita tani yang yang melakukan pengolahan dari hasil lahan pertanian daerah setempat. (2) identifikasi wanita tani/wirausaha yang sudah melakukan pengolahan dari hasil pertanian daerah setempat sesuai standarisasi yang benar sesuai bimbingan dari dinas-dinas yang terkait.

Subyek pengabdian masyarakat pada tahun pertama adalah para wanita tani yang sudah mengolah hasil pertanian dan yang sudah melakukan standarisasi terhadap hasil usahanya. Unsur aparat dinas perindustrian dan perdagangan dan dinas pertanian, dinas koperasi dan dinas terkait lainnya yang bertugas membina pemberdayaan masyarakat wanita tani/UMKM, koperasi di lingkungan wilayah pengabdian masyarakat.

\section{Teknik Pengambilan Data}

Teknik yang digunakan untuk mengumpulkan data adalah dengan focus diskusi grup, obervasi dan dokumentasi. Fokus diskusi grup yang didukung dengan wawancara digunakan untuk mengidentifikasi minat dan kebutuhan masyarakat wanita tani serta warga masyarakat sekitar di lingkungan wilayah obyek pengabdian masyarakat. Observasi digunakan untuk mengamati kondisi dan potensi yang dapat dikembangkan melalui pemasaran hasil pertanian secara online sebagai sarana peningkatan pemberdayaan ekonomi masyarakat- berorientasi pada peningkatan kinerja pemasaran di wilayah pengabdian masyarakat tersebut. Metode dokumentasi digunakan untuk menjaring data yang berhubungan dengun data yang tersimpan dalam dokumen-dokumen di Dinas Perdagangan dan Perindustrian, Dinas Pertanian, Dinas Koperasi di Kabupaten Banyuwangi dan Bojonegoro.

\section{HASIL DAN PEMBAHASAN}

Analisis deskriptif bertujuan untuk menggambarkan karakteristik responden dan jawaban terhadap pernyataan dalam kuesioner untuk masing-masing variabel. Untuk jawaban responden didapat dari besarnya interval kelas mean, kemudian dibuat tentang skala, sehingga dapat diketahui dimana letak rata-rata penilaian responden terhadap setiap variabel yang 
dipertanyakan. Rumus untuk mencari interval kelas menurut Sugiyono (2012:80) adalah sebagai berikut :

$$
\text { Interval Kelas }=\frac{\text { Nilai Tertinggi }- \text { Nilai Terendah }}{\text { Jumlah Kelas }}=\frac{5-1}{5}=0,8
$$

Dengan hasil interval kelas 0,8 , maka dapat disimpulkan tingkatan penilaian sebagai batasan nilai masing-masing kelas kategori dikelompokkan sebagai berikut:

Tabel 1. Kategori Penilaian Berdasarkan Interval

\begin{tabular}{clc}
\hline Interval & \multicolumn{1}{c}{ Kategori } & Nilai \\
\hline $1,00 \leq 1,80$ & Sangat Tidak Setuju (STS) & 1 \\
$1,80 \leq 2,60$ & Tidak Setuju (TS) & 2 \\
$2,60 \leq 3,40$ & Kurang Setuju (KS) & 3 \\
$3,40 \leq 4,20$ & Setuju (S) & 4 \\
$4,20 \leq 5,00$ & Sangat Setuju (SS) & 5 \\
\hline
\end{tabular}

Skala interval diatas untuk memberikan penilaian dalam menjawab pernyataan yang ada pada kuesioner. Sebagaimana dijelaskan dalam definisi operasional variabel dalam pengabdian masyarakat ini antara lain ISO 9001 (X1), merek (X2), kemasan (X3) dan daya saing (Y). Hasil olah data dengan program SPSS 22.0 for windows.

\section{Analisis Deskriptif Variabel ISO 9001 (X1)}

Variabel dalam pengabdian masyarakat ini adalah ISO 9001 (X1) dengan indikator peningkatan kualitas dan peningkatan proses terus-menerus. Tanggapan KWT Jawa Timur terhadap variabel ISO 9001 (X1) dapat dilihat pada Tabel 2 berikut:

Tabel 2. Hasil Tanggapan Responden Terhadap Variabel ISO 9001 (X1)

\begin{tabular}{clcc}
\hline No & \multicolumn{1}{c}{ Pernyataan } & Mean & Std Dev \\
\hline 1 & $\begin{array}{l}\text { Peningkatan kualitas produk secara terus menerus sesuai } \\
\text { kebutuhan konsumen dapat meningkatkan loyalitas } \\
\text { konsumen dalam membeli produk KWT Jawa Timur }\end{array}$ & 3,89 & 0,86 \\
$2 \quad \begin{array}{l}\text { Pencatatan secara terperinci sangat penting guna perbaikan } \\
\text { kualitas secara terus menerus }\end{array}$ & 3,83 & 1,10 \\
$3 \quad \begin{array}{l}\text { Peningkatan proses terus menerus menjadikan pekerjaan } \\
\text { menjadi lebih efektif dan efisien } \\
\text { ISO 9001 berperan penting dalam pemasaran produk KWT }\end{array}$ & 4,12 & 0,79 \\
$\begin{array}{l}\text { Jawa Timur } \\
\text { Persentase produk reject berkurang setelah menerapkan } \\
\text { ISO 9001 }\end{array}$ & 3,83 & 0,90 \\
\hline
\end{tabular}

Berdasarkan Tabel 2 menunjukkan bahwa variabel ISO 9001 (X1) mayoritas responden memberikan pernyataan "Setuju". "Peningkatan kualitas produk secara terus menerus sesuai kebutuhan konsumen dapat meningkatkan loyalitas konsumen dalam membeli produk KWT Jawa Timur" dengan nilai rata-rata sebesar 3,89 dan nilai standar deviasi sebesar 0,86. 
"Pencatatan secara terperinci sangat penting guna perbaikan kualitas secara terus menerus" dengan nilai rata-rata sebesar 3,83 dan nilai standar deviasi sebesar 1,1. "Peningkatan proses terus menerus menjadikan pekerjaan menjadi lebih efektif dan efisien" dengan nilai rata-rata sebesar 4,12 dan nilai standar deviasi sebesar 0,79. "ISO 9001 berperan penting dalam pemasaran produk KWT Jawa Timur" dengan nilai rata-rata sebesar 4,05 dan nilai standar deviasi sebesar 0,9. "Persentase produk reject berkurang setelah menerapkan ISO 9001" dengan nilai rata-rata sebesar 3,83 dan nilai standar deviasi sebesar 0,81 .

\section{Analisis Deskriptif Variabel Merek (X2)}

Variabel dalam pengabdian masyarakat ini adalah merek (X2) dengan indikator kesadaran merek, asosiasi merek, persepsi kualitas dan loyalitas merek. Tanggapan KWT Jawa Timur terhadap variabel merek (X2) dapat dilihat pada Tabel 3 berikut :

Tabel 3. Hasil Tanggapan Responden Terhadap Variabel Merek (X2)

\begin{tabular}{clcc}
\hline No & \multicolumn{1}{c}{ Pernyataan } & Mean & Std Dev \\
\hline 1 & $\begin{array}{l}\text { Konsumen dengan mudah mengenali merek produk KWT } \\
\text { Jawa Timur dengan hanya melihat logo atau ciri khas } \\
\text { produk }\end{array}$ & 3,83 & 0,81 \\
$\quad \begin{array}{l}\text { Produk KWT Jawa Timur sudah masuk ke berbagai pasar } \\
\text { modern sehingga mereknya menjadi lebih dikenal } \\
\text { konsumen }\end{array}$ & 3,93 & 1,02 \\
$3 \quad \begin{array}{l}\text { Persepsi kualitas konsumen terhadap produk KWT Jawa } \\
\text { Timur sangat baik }\end{array}$ & 3,88 & 1,08 \\
$4 \quad \begin{array}{l}\text { Produk KWT Jawa Timur sangat bervariasi dan unik } \\
5\end{array}$ & $\begin{array}{l}\text { Konsumen selalu merekomendasikan merek produk } \\
\text { KWTawa Timur kepada orang lain }\end{array}$ & 3,84 & 1,04 \\
6 & $\begin{array}{l}\text { Secara umum konsumen merasa puas dengan produk } \\
\text { KWT Jawa Timur }\end{array}$ & 3,80 & 0,82 \\
\hline
\end{tabular}

Tabel 3 menunjukkan bahwa variabel merek (X2) mayoritas responden menyatakan "Setuju" "Konsumen dengan mudah mengenali merek produk KWT Jawa Timur dengan hanya melihat logo atau ciri khas produk" dengan nilai rata-rata sebesar 3,83 dan nilai standar deviasi sebesar 0,81. "Produk KWT Jawa Timur sudah masuk ke berbagai pasar modern sehingga mereknya menjadi lebih dikenal konsumen" dengan nilai rata-rata sebesar 3,93 dan nilai standar deviasi sebesar 1,02. "Persepsi kualitas konsumen terhadap produk KWT Jawa Timur sangat baik" dengan nilai rata-rata sebesar 3,88 dan nilai standar deviasi sebesar 1,08 . "Produk KWT Jawa Timur sangat bervariasi dan unik" dengan nilai rata-rata sebesar 3,84 dan nilai standar deviasi sebesar 1,04. "Konsumen selalu merekomendasikan merek produk KWT Jawa Timur kepada orang lain" dengan nilai rata-rata sebesar 3,71 dan nilai standar deviasi sebesar 1,14. "Secara umum konsumen merasa puas dengan produk KWT Jawa Timur" dengan nilai rata-rata sebesar 3,8 dan nilai standar deviasi sebesar 0,82.

\section{Analisis Deskriptif Variabel Kemasan (X3)}

Variabel dalam pengabdian masyarakat ini adalah kemasan (X3) dengan indikator tipografi dalam kemasan, berkomunikasi dengan warna, berkomunikasi dengan citra, struktur dan material kemasan. Tanggapan KWT Jawa Timur terhadap variabel kemasan (X3) dapat dilihat pada Tabel 4 berikut: 
Tabel 4. Hasil Tanggapan Responden Terhadap Variabel Kemasan (X3)

\begin{tabular}{clcc}
\hline No & \multicolumn{1}{c}{ Pernyataan } & Mean & Std Dev \\
\hline 1 & $\begin{array}{l}\text { Tipografi dalam kemasan sangat penting untuk } \\
\text { mengkomunikasi sebuah produk }\end{array}$ & 3,75 & 1,07 \\
2 & $\begin{array}{l}\text { Warna kemasan dengan daya pantul tinggi akan } \\
\text { lebih terlihat dari jarak jauh }\end{array}$ & 3,92 & 0,87 \\
$\quad \begin{array}{l}\text { Citra baik berupa ilustrasi maupun foto pada } \\
\text { kemasan dapat memberikan impresi visual yang } \\
\text { kuat terhadap konsumen }\end{array}$ & 3,80 & 0,82 \\
$4 \quad \begin{array}{l}\text { Struktur kemasan produk KWT Jawa Timur } \\
\text { beranekaragam }\end{array}$ & 4,01 & 0,80 \\
$5 \quad \begin{array}{l}\text { Material kemasan produk KWT Jawa Timur dapar } \\
\text { melindungi produk sampai ke tangan konsumen }\end{array}$ & 3,87 & 1,06 \\
\hline & $\begin{array}{l}\text { Kemasan produk KWT Jawa Timur menarik dan } \\
\text { selalu berinovasi }\end{array}$ & 4,12 & 0,79 \\
\hline
\end{tabular}

Tabel 4 menunjukkan bahwa variabel kemasan (X3) mayoritas responden menyatakan "Setuju" pada pernyataan :

"Tipografi dalam kemasan sangat penting untuk mengkomunikasi sebuah produk" dengan nilai rata-rata sebesar 3,75 dan nilai standar deviasi sebesar 1,07. "Warna kemasan dengan daya pantul tinggi akan lebih terlihat dari jarak jauh" dengan nilai rata-rata sebesar 3,92 dan nilai standar deviasi sebesar 0,87 . "Citra baik berupa ilustrasi maupun foto pada kemasan dapat memberikan impresi visual yang kuat terhadap konsumen" dengan nilai rata-rata sebesar 3,8 dan nilai standar deviasi sebesar 0,82. "Struktur kemasan produk KWT Jawa Timur beranekaragam" dengan nilai rata-rata sebesar 4,01 dan nilai standar deviasi sebesar 0,8. "Material kemasan produk KWT Jawa Timur dapar melindungi produk sampai ke tangan konsumen" dengan nilai rata-rata sebesar 3,87 dan nilai standar deviasi sebesar 1,06, sedangkan pernyataan "Kemasan produk KWT Jawa Timur menarik dan selalu berinovasi" dengan nilai ratarata sebesar 4,12 dan nilai standar deviasi sebesar 0,79.

\section{Pembahasan Data}

Berdasarkan hasil pengabdian masyarakat diketahui bahwa yaitu ISO 9001 (X1), merek (X2) dan kemasan (X3) mempunyai hubungan yang erat dengan daya saing (Y) produk IKM Jawa Timur. Variabel ISO 9001 (X1), merek (X2) dan kemasan (X3) memiliki pengaruh terhadap variabel daya saing $(\mathrm{Y})$ produk di IKM Jawa Timur sebesar $78,9 \%$, sedangkan sisanya sebesar $21,1 \%$ dipengaruhi oleh faktor lain yang tidak termasuk dalam variabel pengabdian masyarakat ini, misalnya harga, promosi, keanekaragaman produk, ukuran produk dan lain sebagainya.

\section{Pengaruh Simultan (Uji F)}

Hasil uji simultan dengan menggunakan nilai Fhitung pada taraf $\alpha=0,05$ sebesar 23,566 $(\mathrm{F} 0,05=23,566)$, dan nilai Fsig sebesar 0,000 berarti nilai Fsig $<0,05$. Karena itu, secara keseluruhan merek, kemasan dan kualitas produk berpengaruh secara signifikan terhadap keputusan pembelian.

Hasil ini menyatakan bahwa variabel ISO 9001 (X1), merek (X2) dan kemasan (X3) secara bersama-sama (simultan) memiliki pengaruh yang signifikan terhadap daya saing $(\mathrm{Y})$ produk IKM 
Jawa Timur. Hal ini dibuktikan dengan Fhitung sebesar 88,275 yang lebih besar daripada Ftabel 2,73 dan nilai siginifikansi sebesar 0,000 , yang lebih kecil dari $\alpha(0,05)$, maka dapat disimpulkan Ho ditolak dan Ha diterima. Bahwa dari hasil uji $\mathrm{F}$ (simultan) diperoleh keterangan bahwa ISO 9001, merek dan kemasan berpengaruh terhadap daya saing produk IKM Jawa Timur. Dengan demikian dapat diambil suatu kesimpulan pada hipotesis pertama yang menyatakan bahwa variabel yaitu ISO 9001 (X1), merek (X2) dan kemasan (X3) secara bersama-sama (simultan) memiliki pengaruh yang signifikan terhadap daya saing (Y) produk di IKM Jawa Timur adalah terbukti kebenarannya. IKM Jawa Timur yang menerapkan ISO 9001 secara konsisten, membangun merek agar produknya dikenal konsumen dan mengemas produknya dengan kemasan yang menarik, maka pangsa pasar produk tersebut akan meningkat sehingga daya saing produk IKM Jawa Timur baik di pasar lokal maupun pasar internasional meningkat.

\section{Pengaruh Parsial (Uji t)}

\section{a. Pengaruh ISO 9001 (X1) terhadap Daya Saing (Y)}

Hasil analisis data pengabdian masyarakat ini diperoleh nilai thitung 7,506, dengan menggunakan taraf signifikansi $5 \%$ dan diperoleh nilai ttabel sebesar 1,665 . Sesuai dengan kerangka berfikir dan hipotesis sementara dapat dijelaskan thitung $=7,506>$ ttabel $=1,665$ dengan signifikansi $0,000<0,05$ sehingga Ho ditolak dan Ha diterima.

Hasil pengabdian masyarakat ini menyatakan bahwa variabel ISO 9001 (X1) secara parsial dan signifikan berpengaruh terhadap daya saing (Y) produk IKM Jawa Timur berdasarkan pengujian nilai koefisien regresi nilai thitung untuk variabel ISO 9001 (X1) sebesar 3,781 dengan tingkat signifikansi sebesar 0,000. Oleh karena itu nilai thitung 3,781 > ttabel 1,994 dan nilai signifikansi yang dihasilkan sebesar 0,000 yang lebih kecil dari 0,05, maka Ho ditolak dan Ha diterima. Dengan demikian berdasarkan hasil tersebut maka dapat diambil suatu kesimpulan pada hipotesis kedua yang menyatakan bahwa pengaruh ISO 9001 (X1) terhadap daya saing (Y) produk IKM Jawa Timur adalah memiliki pengaruh secara parsial dan signifikan ternyata terbukti kebenarannya.

Agar produk IKM Jawa Timur yang memiliki jaminan bahwa kualitasnya konsisten dari waktu ke waktu sehingga daya saing produknya menonjol, maka IKM Jawa Timur harus menerapkan ISO 9001. Dengan menerapkan ISO 9001 maka semua proses yang dikerjakan oleh IKM Jawa Timur telah sesuai dengan prosedur kerja dan instruksi kerja yang telah ditetapkan sehingga konsumen merasa yakin atas kualitas produk tersebut dan daya saing akan meningkat. Selain itu, salah satu persyaratan untuk menembus pasar internasional adalah Sertifikasi ISO 9001.

\section{b. Pengaruh Merek (X2) terhadap Daya Saing (Y)}

Hasil pengabdian masyarakat ini menyatakan bahwa variabel merek (X2) secara parsial dan signifikan berpengaruh terhadap daya saing $(Y)$ produk IKM Jawa Timur berdasarkan pengujian nilai koefisien regresi nilai thitung untuk variabel merek (X2) sebesar 2,529 dengan tingkat signifikansi sebesar 0,014. Dengan nilai thitung 2,529 > ttabel 1,994 dan nilai signifikansi yang dihasilkan sebesar 0,014 yang lebih kecil dari 0,05, maka Ho ditolak dan Ha diterima. Dengan demikian berdasarkan hasil tersebut maka dapat diambil suatu kesimpulan pada hipotesis kedua yang menyatakan bahwa pengaruh merek (X2) terhadap daya saing $(\mathrm{Y})$ produk IKM Jawa Timur adalah memiliki pengaruh secara parsial dan signifikan ternyata terbukti kebenarannya.

Guna menciptakan pangsa pasar yang semakin luas, IKM Jawa Timur harus selalu berusaha untuk membangun merek produknya menjadi kuat. IKM Jawa Timur sebaiknya mendaftarkan 
merek A untuk kualitas A, merek B untuk kualitas B, merek $C$ untuk kualitas $C$, kemudian mengevaluasi merek-merek tersebut segmentasi pasarnya siapa saja. Semakin banyak segmentasi pasarnya maka semakin banyak pelanggan sehingga daya saing produk semakin meningkat.

\section{c. Pengaruh Kemasan (X3) terhadap Daya Saing (Y)}

Hasil pengabdian masyarakat ini menyatakan bahwa variabel kemasan (X3) secara parsial dan signifikan terhadap daya saing $(\mathrm{Y})$ produk IKM Jawa Timur berdasarkan pengujian nilai koefisien regresi nilai thitung untuk variabel kemasan (X3) sebesar 3,013 dengan tingkat signifikansi sebesar 0,004 . Sehingga nilai thitung $3,013>$ ttabel 1,994 dan nilai signifikansi yang dihasilkan sebesar 0,004 yang lebih kecil dari 0,05, maka Ho ditolak dan Ha diterima. Dengan demikian berdasarkan hasil tersebut maka dapat diambil suatu kesimpulan pada hipotesis kedua yang menyatakan bahwa pengaruh kemasan (X3) terhadap daya saing $(\mathrm{Y})$ produk IKM Jawa Timur adalah memiliki pengaruh secara parsial dan signifikan ternyata terbukti kebenarannya. Untuk meningkatkan daya saing produk IKM Jawa Timur, kemasan merupakan salah satu hal yang berperan penting. Dengan kemasan yang unik dan menarik maka konsumen akan lebih fokus untuk melihat produk tersebut, secara tidak langsung hal ini dapat menarik minat konsumen untuk membeli produk tersebut. Dengan kemasan yang mencantumkan label dan iklan pangan yang sesuai dengan kebutuhan konsumen maka konsumen akan lebih yakin bahwa produk yang ada didalam kemasan tersebut telah berstandar dan aman untuk dikonsumsi.

\section{SIMPULAN}

Pengabdian masyarakat dan analisis data pada pengabdian masyarakat mengenai pengaruh ISO 9001 (X1), merek (X2) dan kemasan (X3) terhadap daya saing produk IKM Jawa Timur, maka dapat ditarik simpulan sebagai berikut :

1. Variabel ISO 9001 (X1), merek (X2) dan kemasan (X3) secara bersama-sama (simultan) memiliki pengaruh yang signifikan terhadap daya saing $(\mathrm{Y})$ produk IKM Jawa Timur. IKM Jawa Timur yang menerapkan ISO 9001 secara konsisten, membangun merek agar produknya dikenal konsumen dan mengemas produknya dengan kemasan yang menarik, maka pangsa pasar produk tersebut akan meningkat sehingga daya saing produk IKM Jawa Timur baik di pasar lokal maupun pasar internasional.

2. Variabel ISO 9001 (X1), merek (X2) dan kemasan (X3) berpengaruh secara parsial terhadap daya saing $(Y)$ produk IKM Jawa Timur, sebagaimana berikut:

a. Variabel ISO 9001 (X1) secara parsial dan signifikan berpengaruh terhadap daya saing (Y) produk IKM Jawa Timur. ISO 9001 merupakan suatu sistem untuk memaksimalkan daya saing produk IKM Jawa Timur melalui perbaikan terus-menerus atas pelayanan, proses, output (hasil) dan sumber daya manusia yang berfokus pada kepuasan pelanggan, kualitas produk, adanya kerjasama tim serta perbaikan sistem secara berkesinambungan.

b. Variabel merek (X2) secara parsial dan signifikan berpengaruh terhadap daya saing (Y) produk IKM Jawa Timur. Merek (brand) merupakan salah satu faktor penting untuk meningkatkan daya saing produk IKM Jawa Timur, karena dengan merek konsumen dapat mengenal dengan mudah sebuah produk. Merek merupakan strategi jangka panjang yang memiliki nilai ekonomis bagi konsumen maupun bagi si pemilik merek. IKM 
Jawa Timur telah mendaftarkan merek produknya untuk mendapatkan perlindungan secara hukum.

c. Variabel kemasan (X3) secara parsial dan signifikan terhadap daya saing $(\mathrm{Y})$ produk IKM Jawa Timur. Untuk meningkatkan daya saing produk IKM Jawa Timur, kemasan yang unik dan menarik merupakan salah satu hal yang berperan penting. Kemasan produk IKM Jawa Timur telah mengikuti trend pasar dan sesuai dengan kebutuhan konsumen.

\section{DAFTAR REFERENSI}

Gaspersz, V. (2011) Sistem manajemen kinerja terintegrasi balanced scorecard dengan malcolm baldrige dan lean six sigma supply chain management. Jakarta: PT Gramedia Pustaka Utama.

Hari, Y., Santi, C., \& Dewi, L. P. (2018, September). Interpretasi penetrasi teknologi bagi UMKM dan implikasinya dengan pendekatan Technology Acceptance Model. In Seminar Nasional Sistem Informasi (SENASIF) (Vol. 2, No. 1, pp. 1034-1042).

Hari, Y., Hermawan, B., Widianto, Y., \& Trisno, I. B. (2020). Assesment Online Learning System di Masa Pandemi COVID-19 Menggunakan Metode Technology Acceptance Model. Jurnal Teknik, 18(2), 112-122.

Hari, Y., \& Yanggah, M. E. (2016). Tingkat adopsi inovasi teknologi sistem m-learning dalam pembelajaran bahasa Mandarin pada tingkat SMA.

Ismaini, R. (2015) Pengaruh penerapan sistem manajemen mutu ISO 9001 terhadap kinerja karyawan dan budaya organisasi. Universitas Politeknik Negeri Batam.

Saputro, E. A. (2015) Pengaruh penerapan sistem manajemen mutu ISO 9001:2008 dan kepemimpinan kepala sekolah terhadap kinerja guru di SMK Muhammadiyah 3 Yogyakarta. Universitas Negeri Yogyakarta.

Sari, C. A. S. (2017) Teknik mengelola produk dan merek konsep dan aplikasi pada fast moving consumer goods. Jakarta: PT Gramedia Pustaka Utama.

Tarimana, S. I. (2017) Pengaruh merek, kemasan dan kualitas produk terhadap keputusan pembelian pada Mokko Donut \& Coffee Kendari. Universitas Halu Oleo Kendari.

Wardhani, R. S. dan Agustina, Y. (2015) "Analisis faktor-faktor yang mempengaruhi daya saing pada sentra industri makanan khas bangka di Kota Pangkal Pinang," Akuntansi, hal. 77,92.

Yaman, A. dan Maulana, S. (2016) "Penerapan sistem manajemen mutu ISO 9001:2018 dalam rangka meningkatkan daya saing UMKM di Indonesia," Jurnal, hal. 23-27. 